\title{
Functional responses of stream fish communities to rural and urban a land uses
}

Correspondence: Natali Oliva Roman Miiller natalimiiller@gmail.com

Submitted November 27, 2020

Accepted May 31, 2021

by Fernando Pelicice

Epub Sept 24, 2021

\author{
${ }^{\oplus}$ Natali Oliva Roman Miiller ${ }^{1},{ }^{\oplus}$ Almir Manoel Cunico ${ }^{1,3}$, \\ ${ }^{\oplus}$ Éder André Gubiani ${ }^{2,3}$ and ${ }^{\oplus}$ Pitágoras Augusto Piana ${ }^{2,3}$
}

We tested the effects of ruralization and urbanization on the functional diversity indices and the composition of functional traits of Neotropical stream fish communities. The study was carried out in 24 streams of the Pirapó, Piquiri, Paraná III and Iguassu river basins. Land use in the watershed was categorized as percentages of native vegetation, rural occupation and urban occupation. Statistical tests revealed negative bivariate correlations between functional dispersion and the proportion of native vegetation in the watershed. The results indicate that a higher percentage of rural or urban occupation is associated with increased functional dispersion. In the analyzes of trait composition, significant alterations were observed in response to urbanization while only the increase in herbivory responded to ruralization. As the area of native vegetation is reduced by urbanization, the trait composition changes, with reduced proportions of species with intolerance to hypoxia, migratory reproductive behavior, external fertilization, and subterminal mouth, and increased proportions of species with parental care, detritivory, internal fertilization, and an upper mouth. Therefore, fish species that have these specific characteristics are more likely to disappear from streams as urbanization progresses. In summary, urbanization was related to a greater change in the composition of functional traits than ruralization.

Keywords: Anthropogenic impacts, Functional divergence, Functional traits, Ichthyofauna, Watersheds.
Online version ISSN 1982-0224

Print version ISSN 1679-6225

Neotrop. Ichthyol.

vol. 19, no. 3, Maringá 2021
1 Programa de Pós-Graduação em Aquicultura e Desenvolvimento Sustentável, Laboratório de Ecologia, Pesca e Ictiologia, Universidade Federal do Paraná, Setor Palotina, R. Pioneiro, 2153, Dallas, 85950-000 Palotina, PR, Brazil. (NORM) natalimiiller@gmail.com (corresponding author), (AMC) almircunico@gmail.com.

2 Programa de Pós-Graduação em Conservação e Manejo de Recursos Naturais, Universidade Estadual do Oeste do Paraná, R. da Faculdade, 645, Jadim La Salle, 85903-000 Toledo, PR, Brazil. (EAG) eder.gubiani@unioeste.br, (PAP) pitapiana@yahoo.com.br.

3 Programa de Pós-Graduação em Recursos Pesqueiros e Engenharia de Pesca, Grupo de Pesquisas em Recursos Pesqueiros e Limnologia (Gerpel), Universidade Estadual do Oeste do Paraná, R. da Faculdade, 645, Jardim La Salle, 85903-000 Toledo, PR, Brazil. 
Nós testamos os efeitos da ruralização e da urbanização sobre os índices de diversidade funcional e da composição de traços funcionais em assembleias de peixes de riachos Neotropicais. Amostras foram feitas em 24 riachos distribuídos nas bacias dos rios Pirapó, Piquiri, Paraná III e Iguaçu. O uso do solo foi categorizado por meio das porcentagens de vegetação, ocupação rural e urbana. Testes estatísticos revelaram correlações negativas bivariadas entre a dispersão funcional e a proporção de vegetação. Os resultados indicaram que maior percentual de ocupação rural ou urbana está associado ao aumento da dispersão funcional. Nas análises de composição de traços foram observadas alterações significativas em resposta à urbanização, enquanto apenas o aumento de herbívoros respondeu à ruralização. À medida que a área de vegetação é reduzida, a composição de traços muda, com redução nas proporções de espécies com intolerância à hipóxia, comportamento reprodutivo migratório, fertilização externa e boca subterminal, e aumento da proporção daquelas com cuidado parental, detritivoria, fertilização interna e boca superior. Portanto, espécies que apresentam essas características têm maior probabilidade de desaparecer dos riachos à medida que a urbanização avança. Em resumo, a urbanização foi relacionada a maior alteração na composição de traços funcionais do que a ruralização.

Palavras-chave: Bacia hidrográfica, Divergência funcional, Ictiofauna, Impactos antrópicos, Traços funcionais.

\section{INTRODUCTION}

Humans throughout existence have drastically modified the landscape to meet their needs, generating effects on the structure and composition of biological communities that mirror natural gradients (Concepción et al., 2017; Stephens et al., 2019; Borges et al., 2020). Stream ecosystems are directly and indirectly influenced by past and contemporary land use, thus demonstrating a complicated and long-term imprint of land use in present-day streams (Maloney, Weller, 2011). Legacies of land use from the past, such as the exploitation of native vegetation, ruralization and urbanization have been reported to persist and shape the responses of contemporary communities (Rodrigues-Filho et al., 2018; Chen, Olden, 2020). For example, the pool of regional species of the present may be related to past deterministic processes associated with the conversion of native forest to the agricultural landscape, which selected widely distributed generalist species (Zeni et al., 2020). Community response also may not occur immediately after the land cover change, but become apparent only years later (Camana et al., 2020).

Fish species have long been negatively affected by disturbances due to human activities that degrade aquatic environments (Johann et al., 2019; Carmona et al., 2020), especially in the Neotropical region, which hosts more than $75 \%$ of the global functional diversity of freshwater fish (Toussaint et al., 2016). Brazil is a country that has been unique worldwide in terms of land use, with vast areas of native vegetation that have been converted into farmland and also still safeguards the largest tracts of tropical 
vegetation on Earth, with extremely high levels of biodiversity (Lapola et al., 2014). This scenario is of particular concern because of the megadiversity in this region, which is facing serious political, social and economic challenges for conservation (Vitule et al., 2017; Barbosa et al., 2021).

Concern has been increasing about the loss of fish biodiversity, mainly due to the importance of fishes for ecosystem processes: they influence food webs as consumers or prey; participate in nutrient cycling as excretors, transporters, and decomposers; and modify habitats through sediment bioturbation and substrate bioerosion (Holmlund, Hammer, 1999; Winemiller et al., 2014; Villéger et al., 2017). At a broader level, fish also participate in processes that guarantee the planet's genetic biodiversity, regulate water quality (control of algae biomass), provide sources of protein for human nutrition, and provide cultural services such as sporting fishing recreational and aesthetic value (Villéger et al., 2017; Chen, Olden, 2020). Unfortunately, high levels of habitat degradation place all of these ecosystem services at risk (Cardinale et al., 2012; Vitule et al., 2017).

The removal of native vegetation is one of the first stages of the land occupation process and is generally followed by rural and urban use (Watson et al., 2014). Aquatic ecosystems affected by deforestation and subsequent processes may show increased sedimentation and changes in channel structure that lead to habitat homogenization (Cunico, Gubiani, 2017; Choto, Fetene, 2019), reduced shading and increased solar incidence, which increases water temperature and reduces the concentration of available oxygen (Ceneviva-Bastos, Casatti, 2014; Ilha et al., 2018). They may also exhibit changes in composition and decreases in species richness and abundance (Dala-Corte et al., 2020), which facilitate the invasion of nonnative species (Gaertner et al., 2017; Ruaro et al., 2018; Leitão et al., 2018), as well as increased influx of materials and pollutants from terrestrial ecosystems (Richardson, Sato, 2015; Collins et al., 2016; Johann et al., 2019).

It is recognized that agricultural practices often involve a diverse range of landscape disturbances, ranging from habitat modification due to different crops and pastures to the application of fertilizers and pesticides (Watson et al., 2014). As consequence, fish species that occupy the water column predominate, with large body sizes, that use slow waters, have a preference for sandy substrate, use the marginal portions occupied by grasses and feed mainly on debris and aquatic invertebrates (Teresa, Casatti, 2012). The absence of trophic specialists, of benthic and rheophilic species, are also examples of changes mediated by characteristics in the habitat structure along degradation gradients (Teresa et al., 2015; Dala-Corte et al., 2016). Differently, land-use changes process by urbanization generally is characterized by rates of population growth and infrastructure creation (Parr et al., 2016). The increase of impervious surface cover in urban catchments alters the hydrology and geomorphology of streams, and the runoff from urbanized surfaces, increasing the input of pollutants in the aquatic system (Paul, Meyer, 2001; Baruch et al., 2018). These disturbances select specific functional characteristics and favor species with trophic plasticity, suitable reproductive fitness, and greater tolerance to physical and chemical changes in the habitat (Zeni, Casatti, 2014; Lisi et al., 2018; Johann et al., 2019).

For these reasons, identifying the correlations of biological features with environmental gradients has been an important approach for assessing the integrity of aquatic ecosystems (Villeneuve et al., 2015; Teresa, Casatti, 2017) and especially the effects of environmental changes on functional traits (De-Bello et al., 2010; Carmona et 
al., 2016; Arantes et al., 2017). Approaches based on functional characteristics provide a mechanistic perspective of the species-environment relationship, since the response of a species to an environmental gradient is determined by the set of characteristics that influence the species' performance and persistence (Violle et al., 2007). Studies indicate that the connection between species biodiversity and community functioning is maintained due to complementarity in the use of resources; that is, greater differentiation allows for a better division of resources among species and more effective resource use (MacArthur, Levins, 1967; Mouillot et al., 2007; Leduc et al., 2015). On the other hand, redundant communities can be considered more resilient to species extinctions (McGill et al., 2006).

The increase in agriculture and urbanization inevitably leads to changes in the biodiversity of stream ecosystems. However, few studies have examined the differences in functional responses in a gradient of land use in Neotropical streams. Understanding the effects of land use on aquatic environments, biodiversity and ecosystem functions are highly strategic given that the global conservation of biodiversity is at risk (Lapola et al., 2014). Thus, we aimed to investigate variations in functional diversity and the composition of functional traits of Neotropical stream fish communities. We propose to answer the following questions: Does the increase of different land uses (urban, rural and native vegetation) results in different patterns of functional diversity? Which traits are favored by the increase in the proportion of native vegetation, rural and urban land use? Since removal of native vegetation is generally followed by rural and then urban occupation, we predict that an increase of watershed land use will result in a trait composition most distinguished from that of streams where native vegetation is predominantly. We expect that urbanization will favor species with trophic plasticity, suitable reproductive fitness, and greater tolerance to physical and chemical changes in the habitat. These changes in traits compositions can result in decrease of functional richness due to losses of intolerant species and functional evenness reduction due to dominance of species favored by disturbed environments or extirpations of intolerant species. This study hopes to contribute to the management and monitoring of landscapes in the Neotropical region, since it describes patterns associated with the gradient of land use in Neotropical streams.

\section{MATERIAL AND METHODS}

Study area. The study was carried out in 24 first and second-order streams (sensu Strahler, 1957) in the Pirapó, Paraná III, Piquiri (Upper Paraná Ecoregion sensu Abell et al., 2008) and Iguassu River basins (Iguassu Ecoregion sensu Abell et al., 2008) (Fig. 1; S1), located in the south of Brazil, state of Paraná. The Pirapó River has a length of $168 \mathrm{~km}$ from its head to its mouth on the Paranapanema River and a drainage area of approximately $5,000 \mathrm{~km}^{2}$ (SEMA, 2013). The Paraná III hydrographic basin has a drainage area of $8,389 \mathrm{~km}^{2}$ and is located at the limit of the Itaipu Reservoir, which drastically changed the environments of the region (SEMA, 2013). The Piquiri River basin comprises a drainage area of approximately $25,000 \mathrm{~km}^{2}$ and covers $485 \mathrm{~km}$ before reaching the Paraná River at the entrance to the Itaipu Reservoir (SEMA, 2013). The Iguassu River basin has an extension of $1,320 \mathrm{~km}$ from its headwaters in the east of the 
state to its mouth on the Paraná River, with a drainage area of approximately $70,800 \mathrm{~km}^{2}$ (SEMA, 2013). The lower Iguassu region contains the Iguassu National Park, which houses the largest remnant of the Atlantic Forest (semideciduous season) in southern Brazil, and is the location of the Poço Preto stream (Code 14; Fig. 1), the only stream sampled in the present study with $100 \%$ of its hydrographic basin composed of native vegetation. The predominant landscape in these basins is a mosaic of rural activities and urban development, with remaining areas of Atlantic Forest Biome (SEMA, 2013).

Characterization of land use. To delineate watersheds, we used a digital elevation model (DEM) derived from images of the Shuttle Radar Topography Mission (SRTM), obtained and processed by the Topodata project (www.dsr.inpe.br/topodata). In this DEM each pixel has a set of coordinates $(\mathrm{x}, \mathrm{y})$ and an elevation value $(\mathrm{z})$ corresponding to an area of $30 \mathrm{~m}^{2}$ (Valeriano, Rossetti, 2011). Downloaded Topodata images were processed to the flat coordinate system (UTM) using QGIS (version 3.0.1, QGIS Development Team, 2018). The sampling scale of land use for each stream was delimited by the area of contribution of the watershed obtained through the model TauDEM (Terrain analysis using Digital Elevation Model; Tarboton, 2005) in MapWindow GIS (version 4.8, MapWindow Team Open-Source Software, 2013) according to Nicolete et al. (2015). This model provides the contribution area of each micro basin, calculated through the directions of the hydrographic network flows and the slopes of the terrain (Tarboton, 2005). The point of intersection between the sampled stream and another stream was used as a limit reference for the stream extension. The contribution area of each micro basin was delimited by the highest points of the land around the sampled

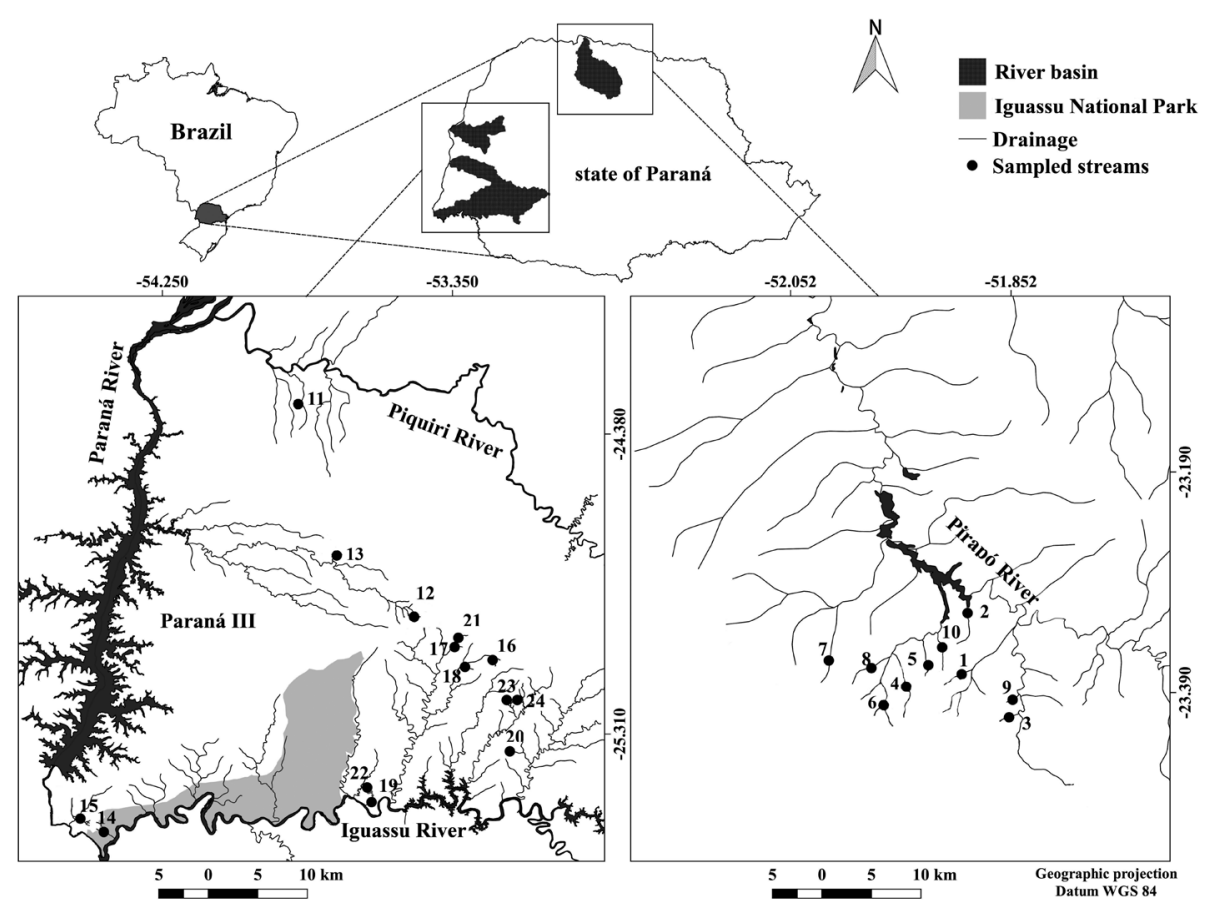

FIGURE 1 I Location of the sampling sites in the 24 streams in the state of Paraná, Brazil. Codes and names of streams in $\mathbf{S 1}$. 
stream. The sampling scale of each micro-basin varied according to the topographic characteristics of the terrain in which the streams are located, and their contribution areas did not overlap.

To classify land use and occupation in the micro basins was used scenes composed of bands obtained from Sentinel-2 EPSG: 4326 satellite, from September 2017 and downloaded from Sentinel Hub by Sinergise (https://apps.sentinel-hub.com/). In the QGIS, the atmospheric correction of the satellite images was performed and the bands were clipped with the shape of the micro basin corresponding to each stream. We used the Semi-Automatic Classification Plugin (SCP) to measure the area proportions of the land use categories native vegetation, rural and urban occupation. The SCP is a complement to QGIS that classifies the bands from pixel to pixel in a semi-automatic way (Congedo, 2017). To confirm that the colors corresponded to classes the areas were supervised using Google Earth ${ }^{\odot}$ (version 7.1.8 and Earth Point ${ }^{\odot}$ 2017). To calculate areas or pixel counts of the classified images, we used the r.report algorithm of GRASS GIS $^{\circledR}$ (version 7.4, GRASS Development Team, 2013) to generate a report listing the number of hectares corresponding to each land use category (see $\mathbf{S} 2$ for area proportions by categories).

Three streams were each composed almost exclusively ( 100\%) of one of the land use categories: native vegetation, rural occupation and urban occupation. Only four streams presented a percentage area of native vegetation greater than $50 \%$ and no urban occupation area. The great majority of streams (19 of 24 ) were less than $30 \%$ occupied by native vegetation (Fig. 2; S3).

Fish sampling. Fish were sampled bimonthly in Pirapó River basin streams and quarterly in the other streams (S1) using three-pass electrofishing depletion surveys in blocked reaches. We used a full-wave rectified pulsed DC electrofisher $(2.5 \mathrm{~kW}, 400$ V, 2 A) operated through two anode dip nets. The sample reach length was determined by multiplying the mean wetted channel width by 20; in meandering streams, 20 times the channel width typically encompasses at least one complete meander wavelength. This approach ensured that all habitat types were represented within each reach (Hauer, Lamberti, 2017).

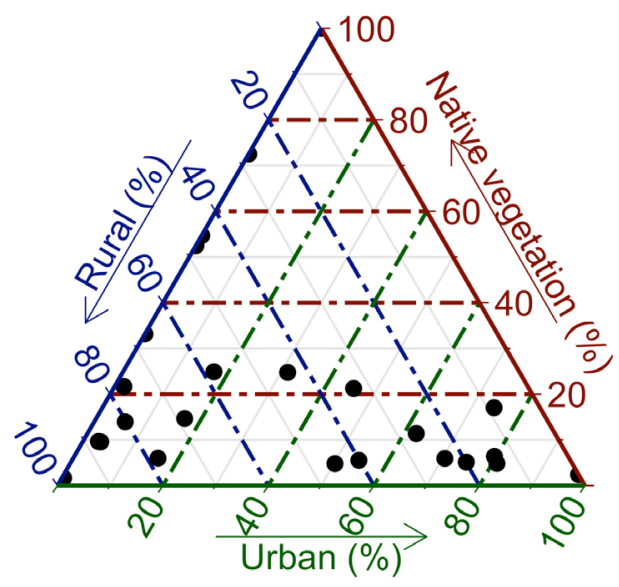

FIGURE 2 I Ternary diagram of land use/occupation in the 24 streams sampled in the state of Paraná, Brazil. 
The fish captured were anaesthetized and euthanized with an overdose of benzocaine and then fixed in plastic bags containing 10\% formalin and packed in polyethene bottles. The specimens were collected under permanent licenses to collect zoological material and by the policies of the Ethical Conduct Committee on Animal Use. In the laboratory, individuals were identified, measured (standard length) and weighed. Identification followed Britski et al. (1999), Reis et al. (2003), da Graça, Pavanelli (2007), Baumgartner et al. (2012), and Ota et al. (2018). Voucher specimens were deposited in the ichthyological collections of Nupelia (NUP) at the Universidade Estadual de Maringá (http://specieslink.net) in Maringá, Museu de Zoologia da Universidade de São Paulo (MZUSP) in São Paulo, Museu de História Natural Capão da Imbuia (MHNCI) in Curitiba, and the ichthyology collection of Grupo de Pesquisas em Recursos Pesqueiros e Limnologia (GERPEL) at the Universidade Estadual do Oeste do Paraná in Toledo.

Functional characterization. We searched the scientific literature and electronic databases to obtain comprehensive functional descriptions of the fish species analyzed in this study (Tab. 1; S4 and S5). We recorded traits related to trophic guild, reproduction, habitat and hypoxia tolerance. In cases where no specific information was available, congeneric species were used as reference. Standard length was obtained as the average value of the measured individuals of each species in each stream. These traits were used to compute the functional diversity indices of richness (FRic), evenness (FEve), divergence (FDiv; Villéger et al., 2008), and dispersion (FDis; Laliberté, Legendre, 2010). The three first indices measure different facets of functional diversity (Mouchet et al., 2010). FRic does not consider the abundance of each species, only its presence, and represents the volume occupied by the community in a multidimensional trait space. In contrast, FEve considers species abundance and represents the regularity of species' distances in multidimensional trait space. It is the opposite of functional redundancy, which assumes that species with the same traits have the same functions in an ecossystem (Ricotta et al., 2016). FDiv ranges from 0 to 1 and indicates whether the most abundant species are near $(\sim 0)$ or far $(\sim 1)$ from the center of multidimentional trait space. However, FDis, which was initially proposed as an index of beta diversity (Anderson, 2006) and subsequently extended to serve as a functional diversity index (Laliberté, Legendre, 2010), both considers the relative abundances of species and measures the mean distance to the centroid of all species in multidimensional trait space. FDis is conceptually similar to Rao's quadratic entropy (Botta-Dukát, 2005).

Data analysis. Values of functional diversity indices (FRic, FEve, FDiv, and FDis) related to the fish community in each stream were obtained by the dbFD function (of the FDpackage; Laliberté, Legendre, 2010; Laliberté et al., 2014) of R (R Core Team, 2016). To use this function, all categorical traits were converted to binary indicator variables, and size, measured as standard length, was standardized by maximum observed value, such that all trait values ranged from zero to one, and Gower's distance was applied (Gower, 1971). The total weight of each species by sample was used as the abundance measure. We use biomass because it provides a direct measure of resource use (Henderson, Magurran, 2010). Lingoes's correction was applied to circumvent the problem of negative eigenvalues (Lingoes, 1971). Then, the obtained functional diversity indices were investigated for relationships with land use, measured as the area 
TABLE 1 I Description of functional traits obtained for fish species sampled in the 24 streams in the state of Paraná, Brazil. ('Mazzoni et al., 2010; Nimet et al., 2015). A same species can present more than one trait of this guild according to its feeding; ${ }^{2}$ Vazzoler, 1996; ${ }^{3} \mathrm{Agostinho}$, Júlio-Jr., 1999; ${ }^{4}$ Mazzoni et al., 2010; ${ }^{5}$ Teresa, Casatti, 2012).

\begin{tabular}{|c|c|c|}
\hline Category & Functional trait & Description \\
\hline \multirow{5}{*}{ Trophic guild ${ }^{1}$} & Carnivorous & Species that feed predominantly on fish, fish fragments and invertebrates. \\
\hline & Detritivorous & Species that feed on detritus. \\
\hline & Omnivorous & Species that feed on plant, algae, detritus and invertebrates. \\
\hline & Invertivorous & Species that feed predominantly on aquatic and terrestrial invertebrates. \\
\hline & Herbivorous & Species that feed on plant material. \\
\hline \multirow{8}{*}{$\begin{array}{l}\text { Reproductive } \\
\text { guild }^{2,3}\end{array}$} & Parental care & $\begin{array}{l}\text { Exhibit well-developed parental care, with nest building or transportation of eggs attached to the } \\
\text { body being common. }\end{array}$ \\
\hline & No parental care & Species that do not care for their eggs and fingerlings. \\
\hline & Internal fertilization & $\begin{array}{l}\text { Species in which the male to use some sort of intromittent organ to deliver sperm into the } \\
\text { genital of the female. }\end{array}$ \\
\hline & External fertilization & Species in which gametes are released directly into the environment. \\
\hline & Total spawning & $\begin{array}{l}\text { Species in which, after maturation of the gonads begins, all the eggs or sperm which are going to } \\
\text { be spawned by the individual fish in a single breeding period develop synchronously. }\end{array}$ \\
\hline & Partial spawning & $\begin{array}{l}\text { Species which spawning by individuals takes place over a protracted period and in which } \\
\text { maturingembryosat different stages of development can be found at any one time in the same } \\
\text { ovary both before and during spawning. }\end{array}$ \\
\hline & Sedentary & Species without migratory behavior. \\
\hline & Migration & Species that require short migrations to spawn. \\
\hline \multirow{4}{*}{ Habitat $^{4}$} & Superior mouth & Mouth is oriented dorsally and the lower jaw is longer than the upper jaw; species are nektonic. \\
\hline & Terminal mouth & Mouth is at the snout tip; species are nektonic and epibenthic. \\
\hline & Subterminal mouth & Mouth is slightly lower than the snout tip; species are benthic and epibenthic. \\
\hline & Inferior mouth & Mouth is oriented ventrally; species are benthic. \\
\hline \multirow{2}{*}{$\begin{array}{l}\text { Hypoxia } \\
\text { tolerance }^{5}\end{array}$} & Tolerant & Species tolerant to oxygen depletion. \\
\hline & Sensitive & Species sensitive to oxygen depletion. \\
\hline Morphology & Length & Tip of the snout to the posterior end of the last vertebra. \\
\hline
\end{tabular}

proportions of native vegetation, rural occupation and urban occupation, by Pearson's correlation analysis (Benesty et al., 2009).

Additionally, community-weighted means (CWMs) of trait values were obtained from the dbFD function. CWM is an index of the functional composition of traits (Lavorel et al., 2008). As we used binary traits, we selected CWMs that represented only the presence of traits and used them to construct a response matrix for the redundancy analysis (RDA, ter Braak, 1986; Legendre, Legendre, 2012). This was done because CWMs of the absence of traits would be ordered in the exactly opposite side of the presence traits, and with the same size. The proportions of native, rural and urban 
vegetation were used as constrained variables in the RDA. The significances of the RDA axes were evaluatad through permutation test ( $n=999$ permutations). Significant axes and CWM ordination results were plotted, and Pearson's correlation coefficients were calculated. For RDA and permutation testing, we used the "rda" and "anova.cca" functions, respectively, of the vegan package (Oksanen et al., 2019) of R. This procedure was carried out in order to identify the influences of ruralization and urbanization over fish traits composition in streams. The level of statistical significance adopted for all analyses (summarized in Fig. 3) was $P<0.05$.

\section{RESULTS}

None of the functional diversity indices was significantly associated with urban or rural occupation. However, negative association of functional dispersion (FDis) with the proportion of native vegetation of streams was found (Tab. 2).

Among the land use types, urban occupation had the strongest effect on trait composition (RDA; axis 1 with $21.61 \%$ of variation explanation; $F_{(1,21)}=6.04 ; \mathrm{p}=0.006$ ), whereas rural had the weakest (Fig. 4). In the analyzes of trait composition, significant alterations were observed in response to urbanization while only the increase in herbivory responded to ruralization. Urbanization favored species presenting tolerance to hypoxia, sedentary behavior, parental care, detritivory, internal fertilization and an upper mouth. In contrast, species that are sensitive to hypoxia, present short-term reproductive migration, do not exhibit parental care, and with a subterminal mouth are more dependent on native environments and are harmed by urbanization (Tab. 2).
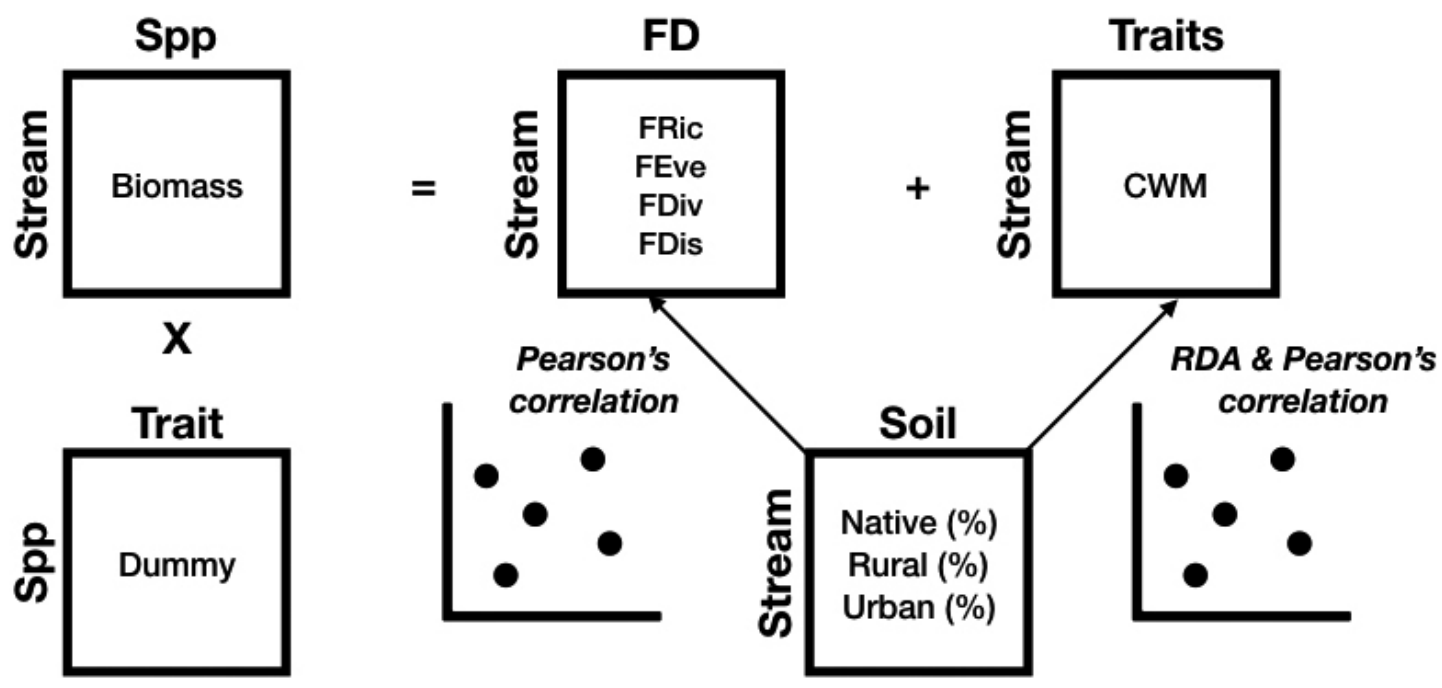

FIGURE 3 I Flowchart of analysis. Biomass and dummy traits matrices were combined to produce functional diversity (FD) indices (FRic $=$ functional richness, FEve $=$ functional evenness, FDiv $=$ functional divergence and FDis $=$ functional dispersion) and community weight mean traits (CWM) matrices. The influences of land use/occupation (Soil matrix) over FD indices were evaluated through Pearson's correlations and over CWM through redundance analysis (RDA) and Pearson's correlations. 


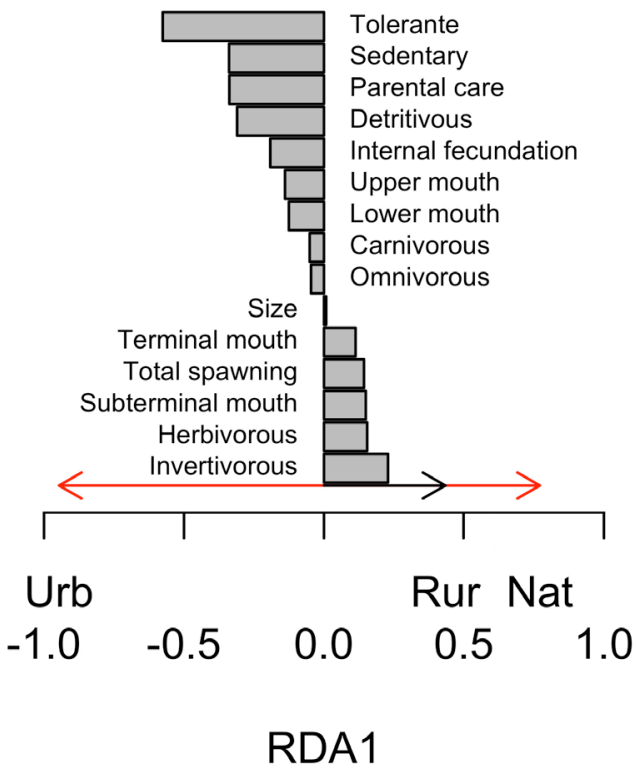

FIGURE 4 I Ordination scores of community-weighted means (CWMs) of traits (gray bars) and proportions of land use/occupation (arrows: biplot scores for constraining variables along of the first principal axis of the redundancy analysis - RDA1) applied to 24 streams sampled in the state of Paraná, Brazil.

TABLE 2 I Pearson correlation ( $r$ ) values describing the correlations between functional diversity indices or community-weighted means (CWMs) of traits and the area proportions of land use/occupation in the 24 streams sampled in the state of Paraná, Brazil. Bold values indicate $p<0.05 ; \mathrm{p}=$ significance.

\begin{tabular}{|c|c|c|c|c|c|c|}
\hline \multirow[b]{3}{*}{ Functional Diversity Indices } & \multicolumn{6}{|c|}{ Proportions } \\
\hline & \multicolumn{2}{|c|}{ Native vegetation } & \multicolumn{2}{|c|}{ Rural } & \multicolumn{2}{|c|}{ Urban } \\
\hline & $r$ & $p$ & $r$ & $p$ & $r$ & $p$ \\
\hline FRic & -0.285 & 0.187 & -0.06 & 0.801 & 0.26 & 0.238 \\
\hline FEve & -0.15 & 0.503 & 0.02 & 0.913 & 0.08 & 0.701 \\
\hline FDiv & 0.23 & 0.288 & -0.12 & 0.600 & -0.06 & 0.771 \\
\hline FDis & -0.43 & 0.034 & -0.08 & 0.694 & 0.39 & 0.058 \\
\hline \multicolumn{7}{|l|}{ Functional Traits } \\
\hline Size & 0.109 & 0.613 & -0.100 & 0.644 & 0.007 & 0.972 \\
\hline Invertivorous & 0.155 & 0.470 & 0.255 & 0.230 & -0.337 & 0.107 \\
\hline Detritivous & -0.449 & 0.028 & -0.232 & 0.275 & 0.533 & 0.007 \\
\hline Herbivorous & -0.042 & 0.846 & 0.430 & 0.036 & -0.347 & 0.097 \\
\hline Omnivorous & -0.191 & 0.371 & -0.131 & 0.540 & 0.256 & 0.228 \\
\hline Carnivorous & 0.079 & 0.714 & -0.228 & 0.284 & 0.142 & 0.507 \\
\hline Terminal mouth & 0.246 & 0.246 & 0.043 & 0.843 & -0.218 & 0.305 \\
\hline Subterminal mouth & 0.558 & 0.005 & 0.103 & 0.632 & -0.500 & 0.013 \\
\hline Lower mouth & -0.346 & 0.097 & -0.028 & 0.895 & 0.279 & 0.187 \\
\hline Upper mouth & -0.419 & 0.042 & -0.175 & 0.413 & 0.461 & 0.023 \\
\hline Total spawning & 0.023 & 0.916 & 0.332 & 0.113 & -0.308 & 0.143 \\
\hline Internal fecundation & -0.336 & 0.109 & -0.361 & 0.083 & 0.563 & 0.004 \\
\hline Parental care & -0.572 & 0.004 & -0.129 & 0.548 & 0.533 & 0.007 \\
\hline Sedentary & -0.573 & 0.003 & -0.085 & 0.692 & 0.495 & 0.014 \\
\hline Tolerance & -0.564 & 0.004 & -0.290 & 0.169 & 0.668 & $<0.001$ \\
\hline
\end{tabular}




\section{DISCUSSION}

Our results indicate that the reduction of native vegetation area is associated with increased FDis, while urbanization and ruralization cause changes in the composition of functional characteristics, restricting or favoring certain traits. Functional dispersion increases when new, distinct traits appear in the community, but because it considers the relative abundance of species, an increase in functional dispersion also indicates that these "arriving traits" are becoming increasingly representative in the community. The RDA results for trait composition are consistent with the patterns in these functional indices and were able to identify relevant alterations related to urbanization and ruralization. Additionally, our results are consistent with those of studies in other streams that evaluated the effects of human activities on the functional diversity of fish communities (Teresa, Casatti, 2012; Teresa et al., 2015; Pereira et al., 2021).

Changes in energy sources and the distribution of resources in degraded aquatic environments have the potential to increase functional dispersion along the gradient of land use by adding functionally different species (Teresa, Casatti, 2012; Barbosa et al., 2020). Land use processes modify environmental characteristics and potentially facilitate the loss of functionally redundant species, with the latter being replaced by species with unique traits (Ernst et al., 2006; Flynn et al., 2009; Villéger et al., 2010).

In addition, the environmental conditions of more degraded streams can increase the diversity of functionally distinct fish species due to the increase in the presence of species tolerant to changes in physical and chemical conditions, like the nonnative species observed in urban streams, Poecilia reticulata and the native species Hypostomus ancistroides, Rhamdia quelen, and Gymnotus inaequilabiatus observed in rural streams.

Non-native species of the genera Poecilia are commonly found in highly degraded environments, especially in urban aquatic environments (Cunico et al., 2012; Daga et al., 2012; Pereira et al., 2021). Similarly, although Siluriformes, such as R. quelen and $H$. ancistroides, and Gymnotiformes, such G. inaequilabiatus are commonly found in small streams, they demonstrate effective strategies in disturbed habitats (Cunico et al., 2012; Daga et al., 2012; Pereira et al., 2021).

The differences in the responses of the fish communities of urban and rural streams in terms of functional diversity are probably related to differences in the type of alteration, magnitude and rate of change of land use among the different watersheds. Urban land use commonly removes most of the riparian vegetation and increase the percentage of impermeable surface areas, while rural land use at least keeps a short vegetation stripe. However, the land use over time is commonly characterized by multiple transitions of land use, e.g., from pristine to agricultural and later to urban use, can exhibit intensified effects on biotic communities (Parr et al., 2016; Chen, Olden, 2020). In this way, we observed evidence of a gradient in which the communities of urban streams present more distinct functional traits, whereas those of rural streams are in the median with respect to trait composition, with a tendency to be more similar to native streams.

This relationship between the rural and native vegetation in the streams evaluated may be related to the application of environmental laws, as the Brazilian Forest Code, that delimits the areas of permanent preservation around water bodies ("New Forest Code", Law 12,651, May 25 2012, Brazil; Soares-Filho et al., 2014). The presence of riparian forest in predominantly rural landscapes appear to create environmental 
conditions that favor the occurrence of tolerant species but also houses a residual fauna of sensitive herbivorous species, highlighting that the increase the percentage of land cover with riparian forest should be a key step to improve the environmental quality in streams under anthropogenic impacts.

The species identified as most likely to be harmed by urbanization in our study are those that exhibit reproductive migration, total spawning, lack parental care and are sensitive to hypoxia, like small Characiformes (e.g., Psalidodon spp. and Astyanax spp.). On the other hand, species with traits that promote greater reproductive plasticity (internal fertilization, partial spawning and parental care), like species of the genera Poecilia, reduce predation on fish eggs and larvae (Fuiman, Magurran, 1994; Klug, Bonsall, 2014), prevent early exposure to pollutants (Newcombe, Jensen, 1996; Pizzolon et al., 2010; Suedel et al., 2017), and increase survival and recruitment in altered habitats are more likely favored by urbanization because they allow the reproductive period to begin when environmental conditions are most favorable (McBride et al., 2015). In addition, feeding specialists with a subterminal mouth, such as invertivorous and herbivorous species (e.g., Piabarchus stramineus, Bryconamericus spp., Piabina sp., Cambeva spp., Trichomycterus spp., Apareiodon spp., Corydoras spp., Callichthys callichthys), are also disfavored and likely to be replaced by detritivore species with an upper mouth (e.g., $P$. reticulata). The dominance of these functional traits can enable the occupation of specific niches and the underutilization of others, reducing complementarity in the use of resources and increasing competition in the community (Tilman, 1999; Lavorel, Garnier, 2002).

Empirical data demonstrate that opportunistic species are widely distributed in disturbed environments and replace sensitive and specialist ones (Devictor et al., 2008). For example, in streams, the biomass of various species of fish, mainly opportunistic, derives from allochthonous food resources, including seeds, fruits, terrestrial insects, as well as decomposing forest vegetation (Marcarelli et al., 2020). However, the fish species that feed on autochthonous resources, such as benthic algae or zooplankton, can benefit from greater aquatic primary production in areas with less dense canopy cover (Allan, 2004). Thus, detritivorous species with ample trophic plasticity (e.g., P. reticulata and Hypostomus spp.) could be favored by habitat alterations promoted by urbanization as observed by our results and previous studies (see Pereira et al., 2021). It is not surprising that functional traits related to reproduction and feeding are mainly responsible for the patterns observed in this study. For example, Keck et al. (2014) demonstrated that functional traits related to reproduction were stronger correlated with changes in environmental variables in a temperate biodiversity hotspot, Tennessee River, USA. Similarly, Ribeiro et al. (2016), using functional traits to assess changes in stream fish assemblages across a habitat gradient in the northwest area of the state of São Paulo in southeast Brazil, demonstrated that feeding traits have a fundamental role in identifying environmental changes in streams.

The intensification of land use by human activities has been associated with changes in functional groups in freshwater aquatic environments, consequently affecting the ecosystemic functions (Díaz et al., 2007; Flynn et al., 2009; Leduc et al., 2015), by modifying the food webs, nutrient cycling and jeopardizing the water quality, as well as the sources of protein for humans (Colvin et al., 2019). Although the Neotropical region contains approximately $75 \%$ of the global functional diversity of freshwater 
fishes (Toussaint et al., 2016), local fish communities of first-order streams typically contain fewer than a dozen species, many endemic species or even species without a taxonomic description (Cilleros et al., 2017; Albert et al., 2020; Frota et al., 2020). Thus, the process of urbanization will certainly result in fish extinctions and consequently loss of functional diversity in a regional and global perspective.

Ourstudy contributes to the understanding of how rural and urban environments affect the biodiversity of stream fish assemblages. We show that ruralization and urbanization increase functional dispersion by increasing the diversity of functionally distinct species along the gradient of land use. We conclude that changes in land cover can eliminate species with characteristics that are poorly adapted to the modified environment but can improve the fitness of other species that are able to benefit from the new conditions. We also found evidence of a gradient wherein urban streams present a set of more distinct functional features, whereas rural ones were more intermediate, tending to be more similar to native streams, highlighting that the increase the percentage of land cover with riparian forest should be a key step to improve the environmental quality in streams under anthropogenic impacts. This study contributes to the scientific framework that assists in the management and monitoring of landscapes in the Neotropical region, since it describes patterns associated with the stages of land occupation or use over time. Ours results also reinforce that the presence of riparian vegetation is an essential strategy for the conservation of stream biodiversity, buffering impacts of land uses.

\section{ACKNOWLEDGMENTS}

This study was financed in part by the Coordenação de Aperfeiçoamento de Pessoal de Nível Superior (CAPES) - Finance Code 001. We would like to thank the researchers and technicians of LEPI-UFPR, GERPEL-UNIOESTE and NUPELIA-UEM that supported us during the present study. Also, we would like to thank MCT/CNPq/CTHidro (Proc. 555185/2006-0) for funding the Pirapó watershed project. ÉAG is grateful to Conselho Nacional de Desenvolvimento Científico e Tecnológico (CNPq) for the continuous research productivity grants (PQ Proc. 308578/2017-1). NROM thanks CAPES for her scholarship. Finally, we have a special acknowledgment to the reviewers for all the contributions that have improved significantly this paper.

\section{REFERENCES}

- Abell R, Thieme ML, Revenga C, Bryer M, Kottelat M, Bogutskaya N et al. Freshwater ecoregions of the world: a new map of biogeographic units for freshwater biodiversity conservation. BioScience. 2008; 58(5):403-14. https://doi.org/10.1641/ B580507

- Agostinho AA, Júlio-Jr HF. Peixes da bacia do alto rio Paraná. In: Lowe-McConnel RH, editor. Estudos ecológicos de comunidades de peixes tropicais. São Paulo: EDUSP; 1999. p.374-400.
- Albert JS, Tagliacollo VA, Dagosta F. Diversification of neotropical freshwater fishes. Annu Rev Ecol Evol Syst. 2020; 51(1):27-53. https://doi.org/10.1146/ annurev-ecolsys-011620-031032

- Allan JD. Landscapes and riverscapes: the influence of land use on stream ecosystems. Annu Rev Ecol Evol Syst. 2004; 35(1):257-84. https://doi.org/10.1146/ annurev.ecolsys.35.120202.110122 
- Anderson MJ. Distance-based tests for homogeneity of multivariate dispersions. Biometrics. 2006; 62(1):245-53. https://doi. org/10.1111/j.1541-0420.2005.00440.x

- Arantes CC, Winemiller KO, Petrere M, Castello L, Hess LL, Freitas CE. Relationships between forest cover and fish diversity in the Amazon River floodplain. J Appl Ecol. 2017; 55(1):386-95. https://doi.org/10.1111/1365-2664.12967

- Barbosa AS, Pires MM, Schulz UH. Influence of land-use classes on the functional structure of fish communities in Southern Brazilian headwater streams. Environ Manage. 2020; 65(5):618-29. https://doi.org/10.1007/s00267-020-01274-9

- Barbosa LC, Alves MAS, Grelle CEV. Actions against sustainability: Dismantling of the environmental policies in Brazil. Land Use Policy. 2021; 104(105384):1-04. https://doi.org/10.1016/j. landusepol.2021.105384

- Baruch EM, Voss KA, Blaszczak JR, Delesantro J, Urban DL, Bernhardt ES. Not all pavements lead to streams: variation in impervious surface connectivity affects urban stream ecosystems. Freshw Sci. 2018; 37(3):673-84. https://doi.org/10.1086/699014

- Baumgartner G, Pavanelli CS, Baumgartner D, Bifi AG, Debona T, Frana VA. Peixes do baixo rio Iguaçu. Maringá: EDUEM; 2012.

- Benesty J, Chen J, Huang Y, Cohen I. Pearson correlation coefficient. In: Benesty J, Chen J, Huang Y, Cohen I. Noise reduction in speech processing. Berlin: Springer; 2009. p.37-40. https://doi.org/10.1007/9783-642-00296-0_5

- Borges PP, Dias MS, Carvalho FR, Casatti L, Pompeu PS, Cetra M et al. Stream fish metacommunity organisation across a Neotropical ecoregion: The role of environment, anthropogenic impact and dispersal-based processes. PLOS ONE. 2020; 15(5):e0233733. https://doi.org/10.1371/ journal.pone.0233733

- Botta-Dukát Z. Rao’s quadratic entropy as a measure of functional diversity based on multiple traits. J Veg Sci. 2005; 16(5):53340. https://doi.org/10.1111/j.1654-1103.2005. tb02393.x

- ter Braak CJF. Canonical correspondence analysis: a new eigenvector technique for multivariate direct gradient analysis. Ecology. 1986; 67(5):1167-79. https://doi. org/10.2307/1938672
- Britski HA, Silimon KZN, Lopes BS. Manual de identificação de peixes do Pantanal. Brasília: EMBRAPA; 1999.

- Camana M, Dala-Corte RB, Collar FC, Becker FG. Assessing the legacy of land use trajectories on stream fish communities of southern Brazil. Hydrobiologia. 2020; 1-16. https://doi. org/10.1007/s10750-020-04347-2

- Cardinale BJ, Duffy JE, Gonzalez A, Hooper DU, Perrings C, Venail P et al. Biodiversity loss and its impact on humanity. Nature. 2012; 486(7401):59-67. https://doi.org/10.1038/nature11148

- Carmona CP, De-Bello F, Mason NHW, Lep J. Traits without borders: Integrating functional diversity across scales. Trends Ecol Evol. 2016; 31(5):382-94. https://doi. org/10.1016/j.tree.2016.02.003

- Carmona CP, Tamme R, Pärtel M, DeBello F, Brosse S, Capdevila P et al. Mapping extinction risk in the global functional spectra across the tree of life. BioRxiv. 2020; e179143. https://doi. org/10.1101/2020.06.29.179143

- Ceneviva-Bastos M, Casatti L. Shading effects on community composition and food web structure of a deforested pasture stream: Evidences from a field experiment in Brazil. Limnologica. 2014; 46:9-21. https://doi.org/10.1016/j.limno.2013.11.005

- Chen K, Olden JD. Threshold responses of riverine fish communities to land use conversion across regions of the world. Global Change Biol. 2020; 26(9):4952-65. https://doi.org/10.1111/gcb.15251

- Choto M, Fetene A. Impacts of land use/ land cover change on stream flow and sediment yield of Gojeb watershed, OmoGibe basin, Ethiopia. Remote Sens Appl. 2019; 14(1):84-99. https://doi.org/10.1016/j. rsase.2019.01.003

- Cilleros K, Allard L, Vigouroux R, Brosse S. Disentangling spatial and environmental determinants of fish species richness and assemblage structure in Neotropical rainforest streams. Freshw Biol. 2017; 62(10):1707-20. https://doi.org/10.1111/ fwb.12981

- Collins SM, Kohler TJ, Thomas SA, Fetzer WW, Flecker AS. The importance of terrestrial subsidies in stream food webs varies along a stream size gradient. Oikos. 2016; 125(5):674-85. https://doi.org/10.1111/ oik.02713 
- Colvin SAR, Sullivan SMP, Shirey PD, Colvin RW, Winemiller KO, Hughes RM et al. Headwater streams and wetlands are critical for sustaining fish, fisheries, and ecosystem services. Fisheries. 2019; 44(2):73-91. https://doi.org/10.1002/ fsh.10229

- Concepción ED, Götzenberger L, Nobis MP, De-Bello F, Obrist MK, Moretti M. Contrasting trait assembly patterns in plant and bird communities along environmental and human-induced landuse gradients. Ecography. 2017; 40(6):75363. https://doi.org/10.1111/ecog.02121

- Congedo L. Semi-automatic classification plugin documentation [Internet]. Release 6.0.1.1; 2017. http://dx.doi.org/10.13140/ RG.2.2.29474.02242/1

- Cunico AM, Ferreira EA, Agostinho AA, Beaumord AC, Fernandes R. The effects of local and regional environmental factors on the structure of fish assemblages in the Pirapó Basin, Southern Brazil. Landsc Urban Plan. 2012; 105(3):336-44. https:// doi.org/10.1016/j.landurbplan.2012.01.002

- Cunico AM, Gubiani ÉA. Effects of land use on sediment composition in low-order tropical streams. Urban ecosyst. 2017; 20(2):415-23. https://doi.org/10.1007/ s11252-016-0603-8

- Daga VS, Gubiani ÉA, Cunico AM, Baumgartner G. Effects of abiotic variables on the distribution of fish assemblages in streams with different anthropogenic activities in southern Brazil. Neotrop Ichthyol. 2012; 10(3):64352. https://doi.org/10.1590/S167962252012000300018

- Dala-Corte RB, Giam X, Olden JD, Becker FG, Guimarães TDF, Melo AS. Revealing the pathways by which agricultural land-use affects stream fish communities in South Brazilian grasslands. Freshw Biol. 2016; 61(11):1921-34. https://doi. org/10.1111/fwb.12825

- Dala-Corte RB, Melo AS, Siqueira T, Bini LM, Martins RT, Cunico AM et al. Thresholds of freshwater biodiversity in response to riparian vegetation loss in the Neotropical region. J Appl Ecol. 2020; 57(7):1391-02. https://doi.org/10.1111/13652664.13657
- De-Bello F, Lavorel S, Díaz S, Harrington $\mathrm{R}$, Cornelissen JHC, Bardgett RD et al. Towards an assessment of multiple ecosystem processes and services via functional traits. Biodivers Conserv. 2010; 19(10):2873-93. https://doi.org/10.1007/ s10531-010-9850-9

- Devictor V, Julliard R, Jiguet F. Distribution of specialist and generalist species along spatial gradients of habitat disturbance and fragmentation. Oikos. 2008; 117(4):507-14. https://doi.org/10.1111/ j.0030-1299.2008.16215.x

- Díaz S, Lavorel S, De-Bello F, Quétier F, Grigulis K, Robson TM. Incorporating plant functional diversity effects in ecosystem service assessments. Proc Natl Acad Sci U S A. 2007; 104(52):20684-89. https://doi.org/10.1073/pnas.0704716104

- Ernst R, Linsenmair KE, Rödel MO. Diversity erosion beyond the species level: Dramatic loss of functional diversity after selective logging in two tropical amphibian communities. Biol Conserv. 2006; 133(2):143-55. http://doi.org/10.1016/j. biocon.2006.05.028

- Flynn DF, Gogol-Prokurat M, Nogeire T, Molinari N, Richers BT, Lin BB et al. Loss of functional diversity under land use intensification across multiple taxa. Ecol Lett. 2009; 12(1):22-33. https://doi. org/10.1111/j.1461-0248.2008.01255.X

- Frota A, Ota RR, Deprá GC, Ganassin MJM, da Graça WJ. A new inventory for fishes of headwater streams from the rio das Cinzas and rio Itararé basins, rio Paranapanema system, Paraná, Brazil. Biota Neotrop. 2020; 20(1):e20190833. https://doi.org/10.1590/1676-0611bn-2019-0833

- Fuiman LA, Magurran AE. Development of predator defences in fishes. Rev Fish Biol Fish. 1994; 4(2):145-83. https://doi. org/10.1007/bf00044127

- Gaertner M, Wilson JR, Cadotte MW, MacIvor JS, Zenni RD, Richardson DM. Non-native species in urban environments: patterns, processes, impacts and challenges. Biol Invasions. 2017; 19:3461-69. https://doi. org/10.1007/s10530-017-1598-7

- Gower JC. A general coefficient of similarity and some of its properties. Biometrics. 1971; 27(4):857-71. Available from: https://www.jstor.org/stable/2528823 
- da Graça MJ, Pavanelli CS. Peixes da planície de inundação do alto rio Paraná e áreas adjacentes. Maringá: EDUEM; 2007.

- GRASS Development Team. Geographic Resources Analysis Support System (GRASS) Software [Internet]. Oregon: Open-Source Geospatial Foundation Project; 2013. Available from: https://www. grass.osgeo.org/grass72/manuals/r.report. html

- Hauer FR, Lamberti G, editors. Methods in stream ecology: Volume 1: Ecosystem structure. London: Academic Press; 2017.

- Henderson PA, Magurran AE. Linking species abundance distributions in numerical abundance and biomass through simple assumptions about community structure. Proc R Soc Lond B Biol Sci. 2010; 277(1687):1561-70. https:// doi.org/10.1098/rspb.2009.2189

- Holmlund CM, Hammer M. Ecosystem services generated by fish populations. Ecol Econ. 1999; 29(2):253-68. https://doi. org/10.1016/S0921-8009(99)00015-4

- Ilha P, Schiesari L, Yanagawa FI, Jankowski K, Navas CA. Deforestation and stream warming affect body size of Amazonian fishes. PLoS ONE. 2018; 13(5):e0196560. https://doi.org/10.1371/ journal.pone.0196560

- Johann AST, Mangolin LP, Sanches PV, Sebastién NY, Topan DA, Piana PA et al. Urbanized tributary causes loss of biodiversity in a Neotropical river segment. Water Air Soil Pollut. 2019; 230(118):1-12. https://doi.org/10.1007/ s11270-019-4164-3

- Keck BP, Marion ZH, Martin DJ, Kaufman JC, Harden CP, Schwartz JS et al. Fish functional traits correlated with environmental variables in a temperate biodiversity hotspot. PLoS ONE. 2014; 9(3):e93237. https://doi.org/10.1371/journal. pone.0093237

- Klug H, Bonsall MB. What are the benefits of parental care? The importance of parental effects on developmental rate. Ecol Evol. 2014; 4(12):2330-51. https://doi. org/10.1002/ece3.1083

- Laliberté E, Legendre P. A distance -based framework for measuring functional diversity from multiple traits. Ecology. 2010; 91(1):299-305. https://doi. org/10.1890/08-2244.1
- Laliberté E, Legendre P, Shipley B. Measuring functional diversity (FD) from multiple traits, and other tools for functional ecology [Internet]. R package version 1.0; 2014. Available from: https:// mran.microsoft.com/snapshot/2014-11-17/ web/packages/FD/FD.pdf

- Lapola DM, Martinelli LA, Peres CA, Ometto JP, Ferreira ME, Nobre CA et al. Pervasive transition of the Brazilian landuse system. Nat Clim Chang. 2014; 4:27-35. https://doi.org/10.1038/nclimate2056

- Lavorel S, Garnier E. Predicting changes in community composition and ecosystem functioning from plant traits: revisiting the Holy Grail. Funct Ecol. 2002; 16(5):545-56. https://doi.org/10.1046/j.13652435.2002.00664.x

- Lavorel S, Grigulis K, McIntyre S, Williams NS, Garden D, Dorrough J et al. Assessing functional diversity in the fieldmethodology matters! Funct Ecol. 2008; 22(1):134-47. https://doi.org/10.1111/j.13652435.2007.01339.x

- Leduc AO, Silva EM, Rosenfeld JS. Effects of species vs. functional diversity: Understanding the roles of complementarity and competition on ecosystem function in a tropical stream fish assemblage. Ecol Indic. 2015; 48:627-35. https://doi.org/10.1016/j. ecolind.2014.09.027

- Legendre P, Legendre L. Numerical ecology. Amsterdam: Elsevier; 2012.

- Leitão RP, Zuanon J, Mouillot D, Leal CG, Hughes RM, Kaufmann PR et al. Disentangling the pathways of land use impacts on the functional structure of fish assemblages in Amazon streams. Ecography. 2018; 41:219-32. https://doi. org/10.1111/ecog.02845

- Lingoes JC. Some boundary conditions for a monotone analysis of symmetric matrices. Psychometrika. 1971; 36(2):195203. https://doi.org/10.1007/BF02291398

- Lisi PJ, Childress ES, Gagne RB, Hain EF, Lamphere BA, Walter RP et al. Overcoming urban stream syndrome: Trophic flexibility confers resilience in a Hawaiian stream fish. Freshw Biol. 2018; 63(5):492-502. https://doi.org/10.1111/ fwb.13091

- MapWindow Team Open-Source Software. MapWindow GIS 4.8 [Internet]; 2013. Available from: http://www. mapwindow.org/ 
- MacArthur RH, Levins R. The limiting similarity, convergence, and divergence of coexisting species. Am Nat. 1967; 101(921):377-85. https://doi. org/10.1086/282505

- Maloney KO, Weller DE. Anthropogenic disturbance and streams: land use and land-use change affect stream ecosystems via multiple pathways. Freshw Biol. 2011; 56(3):611-26. https://doi.org/10.1111/j.1365 2427.2010.02522.x

- Marcarelli AM, Baxter CV, Benjamin JR, Miyake Y, Murakami M, Fausch KD et al. Magnitude and direction of stream-forest community interactions change with timescale. Ecology. 2020; 101(8):e03064. https://doi.org/10.1002/ecy.3064

- Mazzoni R, Moraes M, Rezende CF, Miranda JC. Alimentação e padrões ecomorfológicos das espécies de peixes de riacho do alto rio Tocantins, Goiás, Brasil. Iheringia Ser Zool. 2010; 100(2):16268. https://doi.org/10.1590/S007347212010000200012

- McBride RS, Somarakis S, Fitzhugh GR, Albert A, Yaragina NA, Wuenschel MJ et al. Energy acquisition and allocation to egg production in relation to fish reproductive strategies. Fish Fish. 2015; 16(1):23-57. https://doi.org/10.1111/faf.12043

- McGill BJ, Enquist BJ, Weiher E, Westoby M. Rebuilding community ecology from functional traits. Trends Ecol Evol. 2006; 21(4):178-85. https://doi.org/10.1016/j. tree.2006.02.002

- Mouchet MA, Villéger S, Mason NW, Mouillot D. Functional diversity measures: an overview of their redundancy and their ability to discriminate community assembly rules. Funct Ecol. 2010; 24(4):867-76. https://doi.org/10.1111/j.13652435.2010.01695.x

- Mouillot D, Dumay O, Tomasini JA. Limiting similarity, niche filtering and functional diversity in coastal lagoon fish communities. Estuar Coast Shelf Sci. 2007; 71(3-4):443-56. https://doi.org/10.1016/j. ecss.2006.08.022

- Newcombe CP, Jensen JO. Channel suspended sediment and fisheries: a synthesis for quantitative assessment of risk and impact. N Am J Fish Manage. 1996; 16(4):693-727. https://doi.org/10.1577/15488675(1996)016\%3C0693:CSSAFA\%3E2.3. $\mathrm{CO} ; 2$
- Nicolete DAP, Carvalho TM, Polonio VD, Leda VC, Zimback CRL. Delimitação automática de uma bacia hidrográfica utilizando MDE Topodata: aplicações para estudos ambientais na região da Cuesta de Botucatu - SP [Internet]. João Pessoa: Anais XVII Simpósio Brasileiro de Sensoriamento Remoto; 2015. Available from: http:// marte2.sid.inpe.br/col/sid.inpe.br/ marte2/2015/06.15.15.34.30/doc/p0791.pdf

- Nimet J, Delariva RL, Wolff LL, Silva JC. Trophic structure of fish fauna along the longitudinal gradient of a first-order rural stream. Acta Limnol Bras. 2015; 27(4):381-93. http://dx.doi.org/10.1590/ S2179-975X2915

- Oksanen J, Blanchet FG, Friendly M, Kindt R, Legendre P, McGlinn D et al. Vegan: Community Ecology Package [Internet]. R package version 2.5-6; 2019. Available from: https://CRAN.Rproject.org/ package=vegan

- Ota RR, Deprá GC, da Graça WJ, Pavanelli CS. Peixes da planície de inundação do alto rio Paraná e áreas adjacentes: revised, annotated and updated. Neotrop Ichthyol. 2018; 16(2): e170094. http://doi.org/10.1590/1982-022420170094

- Parr TB, Smucker NJ, Bentsen CN, Neale MW. Potential roles of past, present, and future urbanization characteristics in producing varied stream responses. Freshw Sci. 2016; 35(1):436-43. https://doi. org/10.1086/685030

- Paul MJ, Meyer JL. Streams in the urban landscape. Annu Rev Ecol Syst. 2001; 32: 333-65. https://doi.org/10.1146/annurev. ecolsys.32.081501.114040

- Pereira LM, Dunck B, Benedito E. Human impacts alter the distribuition of fish functional diversity in Neotropical stream system. Biotropica. 2021; 53(2):536-47. https://doi.org/10.1111/btp.12896

- Pizzolon M, Giacomello E, Marri L, Marchini D, Pascoli F, Mazzoldi C et al. When fathers make the difference: efficacy of male sexually selected antimicrobial glands in enhancing fish hatching success. Funct Ecol. 2010; 24(1):141-48. https://doi. org/10.1111/j.1365-2435.2009.01608.x

- QGIS Development Team. QGIS geographic information system [Internet]. Open-source geospatial foundation project; 2018. Available from: http://www.qgis.org/ 
- R Development Core Team. R: a language and environment for statistical computing [Internet]. Vienna: R Foundation for Statistical Computing; 2016. Available from: http://www.R-project.org/

- Reis RE, Kullander SO, Ferraris CJ Jr., editors. Check list of the freshwater fishes of South and Central America. Porto Alegre: Edipucrs; 2003.

- Ribeiro MD, Teresa FB, Casatti L. Use of functional traits to assess changes in stream fish assemblages across a habitat gradient. Neotrop Ichthyol. 2016; 14(1):e140185. https://doi.org/10.1590/19820224-20140185

- Richardson JS, Sato T. Resource subsidy flows across freshwater-terrestrial boundaries and influence on processes linking adjacent ecosystems. Ecohydrology. 2015; 8(3):406-15. https://doi.org/10.1002/ eco.1488

- Ricotta C, De-Bello F, Moretti M, Caccianiga M, Cerabolini BE, Pavoine S. Measuring the functional redundancy of biological communities: a quantitative guide. Methods Ecol Evol. 2016; 7(11):138695. https://doi.org/10.1111/2041-210X.12604

- Rodrigues-Filho CAS, Leitão RP, Zuanon J, Sánchez-Botero JI, Baccaro FB. Historical stability promoted higher functional specialization and originality in Neotropical stream fish assemblages. J Biogeogr. 2018; 45(6):1345-54. https://doi. org/10.1111/jbi.13205

- Ruaro R, Mormul RP, Gubiani ÉA, Piana PA, Cunico AM, da Graça WJ. Non-native fish species are related to the loss of ecological integrity in Neotropical streams: a multimetric approach. Hydrobiologia. 2018; 817:413-30. https://doi.org/10.1007/ s10750-018-3542-y

- Secretaria de Estado do Meio Ambiente e Recursos Hídricos (SEMA). Bacias hidrográficas do Paraná [Internet]. Curitiba; 2013. Available from: https:// www.yumpu.com/pt/document/ $\mathrm{read} / 13725907 /$ serie-historica-2013secretaria-do-meio-ambiente-e-recursos-

- Soares-Filho B, Rajão R, Macedo M, Carneiro A, Costa W, Coe M et al. Cracking Brazil's forest code. Science. 2014; 344(6182):363-64. https://doi.org/10.1126/ science.1246663
- Stephens L, Fuller D, Boivin N, Rick T, Gauthier N, Kay A et al. Archaeological assessment reveals Earth's early transformation through land use. Science. 2019; 365(6456):897-902. https://doi. org/10.1126/science.aax1192

- Strahler AN. Quantitative analysis of watershed geomorphology. Eos (Washington DC). 1957; 38(6):913-20. https://doi.org/10.1029/TR038i006p00913

- Suedel BC, Wilkens JL, Kennedy AJ. Effects of suspended sediment on early life stages of smallmouth bass (Micropterus dolomieu). Arch Environ Contam Toxicol. 2017; 72:119-31. https://doi.org/10.1007/ s00244-016-0322-4

- Tarboton DG. Terrain analysis using digital elevation models (TauDEM) [Internet]. Logan: Utah State University; 2005. Available from: https://hydrology. usu.edu/taudem/taudem3.1

- Teresa FB, Casatti L. Influence of forest cover and mesohabitat types on functional and taxonomic diversity of fish communities in Neotropical lowland streams. Ecol Freshw Fish. 2012; 21(3):433-42. https://doi.org/10.1111/j.16000633.2012.00562.x

- Teresa FB, Casatti L. Trait-based metrics as bioindicators: Responses of stream fish assemblages to a gradient of environmental degradation. Ecol Indic. 2017; 75:249-58. https://doi.org/10.1016/j. ecolind.2016.12.041

- Teresa FB, Casatti L, Cianciaruso MV. Functional differentiation between fish assemblages from forested and deforested streams. Neotrop Ichthyol. 2015; 13(2):36170. https://doi.org/10.1590/1982-022420130229

- Tilman D. Global environmental impacts of agricultural expansion: The need for sustainable and efficient practices. Proc Natl Acad Sci U S A. 1999; 96(11):5995-6000. https://doi.org/10.1073/ pnas.96.11.5995

- Toussaint A, Charpin N, Brosse S, Villéger S. Global functional diversity of freshwater fish is concentrated in the Neotropics while functional vulnerability is widespread. Sci Rep. 2016; 6(22125):1-09. https://doi.org/10.1038/srep22125

- Valeriano MM, Rossetti DF. Topodata: Brazilian full coverage refinement of SRTM data. Appl Geogr. 2011; 32(2):300-09. https://doi.org/10.1016/j. apgeog.2011.05.004 
- Vazzoler AEAM. Biologia da reprodução de peixes teleósteos: teoria e prática. Maringá: Eduem; 1996.

- Villéger S, Brosse S, Mouchet M, Mouillot D, Vanni MJ. Functional ecology of fish: current approaches and future challenges. Aquat Sci. 2017; 79:783-801. https://doi. org/10.1007/s00027-017-0546-Z

- Villéger S, Mason NW, Mouillot D. New multidimensional functional diversity indices for a multifaceted framework in functional ecology. Ecology. 2008; 89(8):2290-301. https://doi.org/10.1890/071206.1

- Villéger S, Miranda JR, Hernández DF, Mouillot D. Contrasting changes in taxonomic vs. functional diversity of tropical fish communities after habitat degradation. Ecol Appl. 2010; 20(6):151222. https://doi.org/10.1890/09-1310.1

- Villeneuve B, Souchon Y, UsseglioPolatera P, Ferréol M, Valette L. Can we predict biological condition of stream ecosystems? A multi-stressors approach linking three biological indices to physicochemistry, hydromorphology and land use. Ecol Indic. 2015; 48:88-98. https://doi. org/10.1016/j.ecolind.2014.07.016

- Violle C, Navas ML, Vile D, Kazakou E, Fortunel C, Hummel I et al. Let the concept of trait be functional! Oikos. 2007; 116(5):882-92. https://doi.org/10.1111/ j.0030-1299.2007.15559.x
- Vitule JR, Costa APL, Frehse FA, Bezerra LAV, Occhi TVT, Daga VS et al. Comment on 'Fish biodiversity and conservation in South America by Reis et al. (2016)'. J Fish Biol. 2017; 90(4):1182-90. https://doi. org/10.1111/jfb.13239

- Watson SJ, Luck GW, Spooner PG, Watson DM. Land-use change: incorporating the frequency, sequence, time span, and magnitude of changes into ecological research. Front Ecol Environ. 2014; 12(4):241-49. https://doi. org/10.1890/130097

- Winemiller KO, Montaña CG, Roelke DL, Cotner JB, Montoya JV, Sanchez L et al. Pulsing hydrology determines top-down control of basal resources in a tropical river-floodplain ecosystem. Ecol Monogr. 2014; 84(4):621-35. https://doi. org/10.1890/13-1822.1

- Zeni JO, Casatti L. The influence of habitat homogenization on the trophic structure of fish fauna in tropical streams. Hydrobiologia. 2014; 726:259-70. https:// doi.org/10.1007/s10750-013-1772-6

- Zeni JO, Hoeinghaus DJ, Roa-Fuentes CA, Casatti L. Stochastic species loss and dispersal limitation drive patterns of spatial and temporal beta diversity of fish assemblages in tropical agroecosystem streams. Hydrobiologia. 2020; 847:3829-43. https://doi.org/10.1007/s10750-020-04356-1

\section{AUTHORS' CONTRIBUTION}

Natali Oliva Roman Miiller: Formal analysis, Methodology, Writing-original draft.

Almir Manoel Cunico: Conceptualization, Formal analysis, Investigation, Methodology, Resources, Supervision, Writing-original draft.

Éder André Gubiani: Conceptualization, Formal analysis, Methodology, Writing-original draft.

Pitágoras Augusto Piana: Formal analysis, Methodology, Supervision, Writing-original draft.

\section{ETHICAL STATEMENT}

Permit number 24680-1, Sistema de Autorização e Informação em Biodiversidade (SISBIO) to Almir M. Cunico. The research was conducted in accordance with the policies of the Ethical Conduct Committee on Animal Use (CEUA) as administered by the Universidade Federal do Paraná/Protocol 26/2012. Permit number 755/2008, Instituto Ambiental do Paraná, to Éder A. Gubiani. The research was conducted were collected following ethical precepts in animal experimentation.

\section{COMPETING INTERESTS}

The authors declare no competing interests. 


\section{Neotropical Ichthyology}

open Access

(c) (1)

This is an open access article under the terms of the Cre use, distribution and reproduction in any medium,

Distributed under

Creative Commons CC-BY 4.0

๑ 2021 The Authors.

Diversity and Distributions Published by SBI

\section{Official Journal of the}

SBI
HOW TO CITE THIS ARTICLE

- Miiller NOR, Cunico AM, Gubiani ÉA, Piana PA. Functional responses of stream fish communities to rural and urban land uses. Neotrop Ichthyol. 2021; 19(3):e200134. https:// doi.org/10.1590/1982-0224-2020-0134 